\begin{tabular}{|c|c|c|}
\hline 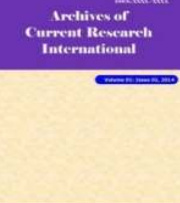 & $\begin{array}{c}\text { Archives of Current Research International } \\
6 \text { (1): 1-6, 2016, Article no.ACRI.29464 } \\
\text { ISSN: } 2454-7077\end{array}$ & SCIENCEDOMAIN \\
\hline 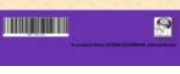 & $\begin{array}{l}\text { SCIENCEDOMAIN international } \\
\text { www.sciencedomain.org }\end{array}$ & \\
\hline
\end{tabular}

\title{
Study on Physicochemical Properties of Edible Oils Available in Bangladeshi Local Market
}

\author{
Md. Sabbir Hasan ${ }^{1}$, Rownok Jahan ${ }^{1}$, Md. Ashraful Alam¹, Mst. Khodeza Khatun ${ }^{1}$ \\ and Sharif M. Al-Reza ${ }^{1^{*}}$ \\ ${ }^{1}$ Department of Applied Chemistry and Chemical Technology, Islamic University, Kushtia, \\ Bangladesh. \\ Authors' contributions
}

This work was carried out in collaboration between all authors. All authors read and approved the final manuscript.

Article Information

DOI: $10.9734 / \mathrm{ACRI} / 2016 / 29464$

Editor(s):

(1) Jack Wong, Department of Cardiovascular Sciences, Institute for Academic Medicine, Houston Methodist Research Institute, USA and Department of Cardiothoracic Surgery, Weill Cornell Medical College of Cornell University, USA.

Reviewers:

(1) Ekebafe Olu Lawrence, Auchi Polytechnic, Auchi, Nigeria. (2) Nikesh Samarth, Institute of Chemical Technology, Mumbai, India. Complete Peer review History: http://www.sciencedomain.org/review-history/16685

Original Research Article

Received $12^{\text {th }}$ September 2016

Accepted $15^{\text {th }}$ October 2016

Published $26^{\text {th }}$ October 2016

\section{ABSTRACT}

Aims: The aim of this study is the qualitative evaluation of the edible oils that are used for cooking purpose in Bangladesh.

Study Design: This study was designed for selecting a good quality edible oil among various edible oils available in the local market of Bangladesh.

Place and Duration of Study: Sample: Sixteen brands of different oil samples were purchased from local market of Jhenidah city of Bangladesh. The research was carried out at natural product research laboratory, Dept. of Applied Chemistry \& Chemical Technology, Islamic university, Kushtia, Bangladesh during June-July 2016.

Methodology: The quality of edible oils was analyzed by evaluating physicochemical properties such as density, moisture content, boiling point, peroxide, acid, iodine and saponification values using standard methods.

Results: In this study oils from different brand were investigated to determine the physicochemical properties like density, moisture content, boiling point, saponification value (SV), peroxide value (PV), acid value (AV) and iodine value (IV). Highest density observed in Deshi/Ghani mustard oil $(0.9683 \mathrm{~g} / \mathrm{ml})$ and lowest in Mustafa soybean oil $(0.901 \mathrm{~g} / \mathrm{ml})$. On the other hand, moisture content was observed in between $0.2 \%$ to $0.82 \%$. The highest and lowest saponification value was

*Corresponding author: Email: sharif1435@gmail.com, sharif@acct.iu.ac.bd; 
obtained $211.4 \mathrm{mg} \mathrm{KOH} / \mathrm{g}$ for Jui coconut oil and $158.55 \mathrm{mg} \mathrm{KOH} / \mathrm{g}$ for Deshi/Ghani mustard oil, respectively. It was observed that Olive oil showed maximum (12.43 $\mathrm{meq} \mathrm{O}_{2} / \mathrm{kg}$ ) and Teer soybean oil showed minimum $\left(1.01 \mathrm{meq} \mathrm{O}_{2} / \mathrm{kg}\right.$ ) peroxide values. Highest acid value was observed in Jui coconut oil $(18.04 \mathrm{mg} \mathrm{KOH} / \mathrm{g})$ and lowest in Fresh soybean oil $(0.36 \mathrm{mg} \mathrm{KOH} / \mathrm{g})$. On the contrary, highest iodine value was observed in Rupchanda soybean oil (109.96 g I2/g oil) and lowest in Jui coconut oil $\left(6.48 \mathrm{~g} \mathrm{I}_{2} / \mathrm{g}\right.$ oil).

Conclusion: The results will help us for selecting a good quality edible oil.

Keywords: Edible oils; density; moisture content; boiling point; saponification value; peroxide value; acid value; iodine value.

\section{INTRODUCTION}

Edible oils are vital constituents of our daily diet which provide energy, essential fatty acids and serve as a carrier of fat soluble vitamins [1]. $10 \%$ or fewer of calories consumed daily should be from saturated fat and $20-35 \%$ of total daily calories come from polyunsaturated and monounsaturated fats. Small amounts of saturated fats is common in diets, meta-analyses found a significant correlation between high consumption of saturated fats and blood LDL concentration, a risk factor for cardiovascular diseases. Saturated fats be replaced with polyunsaturated and monounsaturated fats. Olive and canola oils as sources of healthier monounsaturated oils while soybean and sunflower oils as good sources of polyunsaturated fats. One study showed that consumption of non-hydrogenated unsaturated oils like soybean and sunflower are preferable to the consumption of palm oil for lowering the risk of heart disease [2]. Atmospheric oxygen reacts instantly with lipid and other organic compounds of the oil to cause structural degradation in the oil which leads to loss of quality of food and is harmful to human health [3]. Different physical and chemical parameters of edible oil were used to monitor the compositional quality of oils [4]. Therefore, it is essential to monitor the quality of oil to avoid the use of abused oil. These physicochemical parameters including density, moisture content, boiling point, saponification value, peroxide value, acid value and iodine value which is used to assess the quality and functionality of the oil [5]. A good type edible oil which can be used as cooking purpose must consider with a proved range of the physicochemical parameters. By understanding the properties we can evaluate the oil for human health consideration, industrial application etc. Low density oils are highly appreciable to consumers [6]. Oils having higher value of the moisture content can be used for food texturing, baking,and frying and industrially in the manufacture ofsoaps, detergents, cosmetics and oil paints [7]. The higher the saponification value values,the shorter the average chain length of the fatty acids and the lower the average molecular weight of the fatty acids and viceversa [8]. By the study of peroxide value, the quality and stability of oils can be indicated by measuring the rancidity reactions have occurred during storage. Increase in peroxide value indicates the rancidity of oils due to relative higher oxidation in oils [9]. Higher acid value indicates that triglycerides of oil are converted into fatty acids and glycerol which cause rancidity of the oil [1]. So, the cooking oils must have lower acid value otherwise the oil can damage human health. lodine value measures the degree of unsaturation in a fat or vegetable oil [10]. The higher the unsaturation, the greater the possibility of the oils to go to rancid [9]. Several researchers studied the physicochemical parameters to assess the quality and functionality of the oil $[6,11]$. The parameters can identify the characteristics of edible oils available in Bangladeshi market whose characteristics remain indistinct and for this, the quality of individual edible oil also remains unknown.

\section{MATERIALS AND METHODS}

\subsection{Sample Collection}

Sixteen brands of different oil samples were purchased from local market of Jhenidah city of Bangladesh.

\subsection{Density Measurement}

Densities of oil samples were measured by a Relative Density (R.D) bottle with a capacity of $10 \mathrm{ml}$ according to the following formula:

$$
\operatorname{Density}(\rho)=\frac{\text { Mass of the oil sample }(M)}{\text { Volume of the R.D bottle }(\mathrm{V})} \mathrm{g} / \mathrm{ml}
$$




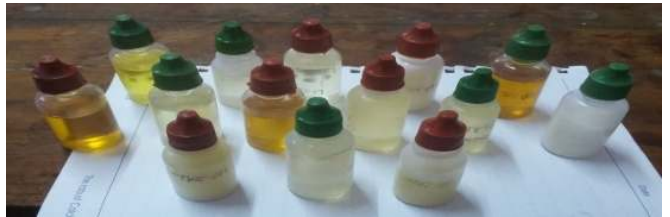

Fig. 1. Different oil samples

\subsection{Moisture Content}

Three crucibles were weighed and into each 10 $\mathrm{g}$ of the oil sample were added. The samples were dried to constant weights in an oven at $105^{\circ} \mathrm{C}$, cooled in desiccators and weighed. The procedure was repeated thrice for each sample and the average value was determined [12].

\subsection{Boiling Point Determination}

The boiling point of oil samples were determined by a thermometer $\pm 1^{\circ} \mathrm{C}$. The boiling point depends upon the degree of unsaturation of fatty acids [1].

\subsection{Saponification Value}

The saponification value is determined by taking $1.0 \mathrm{~g}$ of oil sample in a conical flask to which is added $25 \mathrm{ml} 0.5 \mathrm{~N}$ alcoholic $\mathrm{KOH}$ heated under a reserved condenser for 30-40 min to ensure that the sample was fully dissolved. After cooling the sample, phenolphthalein was added and titrated with $0.2 \mathrm{~N} \mathrm{HCl}$ until a pink end point was reached. A blank was determined with the same time conditions [9].

$$
\begin{aligned}
& \text { Saponification value }=\frac{(B-T) \times N \times 56.1}{W} \\
& B=m l \text { of } \mathrm{HCl} \text { required by blank } \\
& T=m l \text { of } \mathrm{HCl} \text { required by oil sample } \\
& \mathrm{N}=\text { Normality of } \mathrm{HCl} \\
& \mathrm{W}=\text { Weight of oil in } \mathrm{gm}
\end{aligned}
$$

\subsection{Peroxide Value}

The peroxid value is a measure of the concentration of substances that oxidize potassium iodide to iodine. A known measured weight of oil samples is dissolved in acetic acid then chloroform and saturated $\mathrm{KI}$ mixture are added to the sample and the amount of iodine liberated from $\mathrm{KI}$ by the oxidative action of peroxides present in the oil is determined by titration with $0.1 \mathrm{~N}$ sodium thiosulphate using starch solution as an indicator. Titration was also performed for blanks $[13,14]$.

$$
\begin{aligned}
& \text { Peroxide value }\left(\text { meq } \mathrm{O}_{2} / \mathrm{kg} \text { oil }\right)=(\mathrm{S}-\mathrm{B}) \times \mathrm{W} \times \mathrm{N} \\
& \mathrm{S}=\begin{array}{l}
\text { Volume of sodium thiosulphate } \\
\text { consumed by the sample oil }
\end{array} \\
& \mathrm{B}=\begin{array}{l}
\text { Volume of sodium thiosulphate used for } \\
\text { blank }
\end{array} \\
& \mathrm{W}=\text { Weight of oil sample } \\
& \mathrm{N}=\text { the normality of sodium thiosulphate }
\end{aligned}
$$

\subsection{Acid Value}

The acid value of oils was determined titremetric method according to AOAC (Association of Official Analytical Chemists) method [15]. About $5 \mathrm{~g}$ of oils were taken in $250 \mathrm{ml}$ conical flask. Then $25 \mathrm{ml}$ of neutral ethyl alcohol was added to it and then boiled on water bath. Phenolphthalein indicator solution (1-2 drop) was added then the mixture while hot was titrated against with standard potassium hydroxide solution with shaking. The end point was noted to the first pink colour which persist for 30 seconds [10]. Acid value was calculated as $\mathrm{mg}$ of $\mathrm{KOH}$ per gm of Oil.

$$
\text { Acid value }=\frac{V \times N \times 56.1}{W}
$$

$\mathrm{V}=$ Volume of standard $\mathrm{KOH}$ solution in $\mathrm{ml}$ $\mathrm{N}=$ Normality of standard $\mathrm{KOH}$ solution.

$\mathrm{W}=$ Weight of oil sample in grams.

\section{8 lodine Value}

The iodine value of oils was determined according to AOAC method [9]. About $0.25 \mathrm{~g}$ oil sample was taken in a conical flask and dissolved in $10 \mathrm{ml} \mathrm{CCl}_{4} .30 \mathrm{ml}$ hanus solution was added and the mixture was allowed to stand for $45 \mathrm{~min}$ in dark with occasional shaking. $10 \mathrm{ml}$ $10 \% \mathrm{KI}$ solution and $100 \mathrm{ml}$ distilled water were added and washed down any free iodine on the stopper. The iodine was titrated with previously standardized $\mathrm{Na}_{2} \mathrm{~S}_{2} \mathrm{O}_{3}$ solution which added gradually with constant shaking until yellow solution turned almost colorless. Few drops of starch indicator was added and titration was continued until blue color entirely disappeared. Bottle was shaken violently so that any iodine remaining in solution in the $\mathrm{CCl}_{4}$ might be taken up by the $\mathrm{KI}$ solution. The volume of $\mathrm{Na}_{2} \mathrm{~S}_{2} \mathrm{O}_{3}$ solution required for the experiment was noted. A blank experiment was conducted along with 
the sample. Percent weight of iodine absorbed by the oil sample was calculated by the following formula:

$$
\begin{aligned}
& 1 \mathrm{ml} 1 \mathrm{~N} \mathrm{Na} \mathrm{S}_{2} \mathrm{O}_{3}=0.127 \mathrm{~g} \mathrm{I}_{2} \\
& \text { Iodine value }=\frac{(\mathrm{B}-\mathrm{A}) \times \mathrm{N} \times 0.127 \times 100}{\mathrm{~W}} \\
& \mathrm{~B}=\mathrm{ml} \text { of } 0.1 \mathrm{~N} \mathrm{Na}_{2} \mathrm{~S}_{2} \mathrm{O}_{3} \text { required by blank } \\
& \mathrm{A}=\text { ml of } 0.1 \mathrm{~N} \mathrm{Na}_{2} \mathrm{~S}_{2} \mathrm{O}_{3} \text { required by oil } \\
& \quad \text { sample } \\
& \mathrm{N}=\text { Normality of } \mathrm{Na}_{2} \mathrm{~S}_{2} \mathrm{O}_{3} \\
& \mathrm{~W}=\text { Weight of oil in } \mathrm{g}
\end{aligned}
$$

\section{RESULTS AND DISCUSSION}

The quality of edible oils was analyzed by evaluating physicochemical properties such as density, moisture content, boiling point, peroxide, acid, iodine and saponification values. Results are presented in Table 1. In order to design an advanced technological process these properties are very important parameters.

\subsection{Density}

Oils with the density of lower values are highly appreciable to consumers. The results tabulated in Table 1 show that at room temperature of $25^{\circ} \mathrm{C}$ highest and lowest values of the densities are $0.9683 \mathrm{~g} / \mathrm{ml}$ and $0.901 \mathrm{~g} / \mathrm{ml}$ for Deshi/Ghani mustard oil and Mustafa soybean oil, respectively. This is because, the $\pi$ bonds that make the bonding more rigid androtation between $\mathrm{C}-\mathrm{C}$ bonds becomes more strenuous [7].

\subsection{Moisture Content}

Palm oil and Rice bran oil have moisture content of $0.2 \%$ and $0.82 \%$ as lowest and highest values, respectively. The higher the value of the moisture content of the oil, the greater the value used for food texturing, baking, and frying and industrially in the manufacture of soaps, detergents, cosmetics and oil paints [8].

\subsection{Saponification Value}

Saponification value provides the information of the average chain length and hence the molecular weight of the fatty acid in the oil. The shorter the average chain length of the fatty acids, the higher the saponification value and the lower the average molecular weight of the fatty acids and vice-versa [10].

The Saponification value obtained for the oil samples in Table 1 showed that $211.4 \mathrm{mg}$ $\mathrm{KOH} / \mathrm{g}$ for Jui coconut oil and $158.55 \mathrm{mg} \mathrm{KOH} / \mathrm{g}$ for Deshi/Ghani mustard oil as highest and lowest value, respectively. The lower saponification values suggests that the mean molecular weight of fatty acids is lower or that the number of ester bonds is less. This might imply that the fat molecules did not interact with each other [16].

\subsection{Peroxide Value}

Peroxide value is used as a measure of the extent to which rancidity reactions have occurred during storage. The quality and stability of fats and oils can be indicated by using the peroxide value [11]. In the study, soybean oils and palm oil showed the lower peroxide values in the range of 1-2 meq $\mathrm{O}_{2} / \mathrm{kg}$ oil which indicates a relatively good quality of these oils. On the other hand, mustard oils, castor oil, almond oil, olive oil showed higher the values in the range of 5-13 meq $\mathrm{O}_{2} / \mathrm{kg}$ oil. There is a successive increase in peroxide value indicates the rancidity of oils due to relative higher oxidation in oils. Peroxide value ranges are closely related to the standard value of 10 meq $\mathrm{O}_{2} / \mathrm{kg}$ as specified [7].

\subsection{Acid Value}

Acid value of oils indicates the amount of free fatty acid present in the oil. It determines the purity of oils. The higher the values, the lower the possibility of the oils to be used as cooking purpose. It was observed that higher and lower acid values obtained forJui coconut oil and Fresh soybean oil were 18.04 and 0.36 , respectively. Higher values indicates that triglycerides of oil are converted into fatty acids and glycerol which cause rancidity of the oil [1].

\section{6 lodine Value}

lodine value (IV) measures the degree of unsaturation in a fator vegetable oil. It determines the stability of oils to oxidation and allows the overall unsaturation of the fat to be determined qualitatively [12]. It was observed that higher and lower iodine values obtained for Rupchanda soybean oil and Jui coconut oil were $109.96 \mathrm{~g}$ and $6.48 \mathrm{~g}$, respectively. The lower iodine value of coconut oil indicates that 
Table 1. Physicochemical properties of some edible oils available in Bangladesh

\begin{tabular}{|c|c|c|c|c|c|c|c|}
\hline Name of the oils & $\begin{array}{l}\text { Density } \\
(\mathrm{g} / \mathrm{ml})\end{array}$ & $\begin{array}{l}\text { Moisture } \\
\text { content } \\
(\%)\end{array}$ & $\begin{array}{l}\text { Boiling } \\
\text { point } \\
\text { (') }\end{array}$ & $\begin{array}{l}\text { Saponific- } \\
\text { ation value } \\
(\mathrm{mg} \mathrm{KOH} / \mathrm{g})\end{array}$ & $\begin{array}{l}\text { Peroxide } \\
\text { value } \\
\text { (meq } \\
\mathrm{O}_{2} / \mathrm{kg} \text { ) }\end{array}$ & $\begin{array}{l}\text { Acid } \\
\text { value } \\
(\mathrm{mg} \\
\mathrm{KOH} / \mathrm{g})\end{array}$ & $\begin{array}{l}\text { lodine } \\
\text { value } \\
\left(\mathrm{g} \mathrm{I}_{2} / 100\right. \\
\mathrm{g} \mathrm{oil})\end{array}$ \\
\hline Mustafa soybean oil & 0.901 & 0.53 & 185 & 182.12 & 1.62 & 0.37 & 85.4 \\
\hline Muskan soybean oil & 0.9103 & 0.45 & 178 & 183.7 & 2.09 & 0.73 & 105.7 \\
\hline Pusti soybean oil & 0.9043 & 0.48 & 196 & 183.35 & 1.72 & 0.56 & 89.8 \\
\hline Teer soybean oil & 0.9182 & 0.22 & 188 & 187.13 & 1.01 & 0.38 & 90.16 \\
\hline Fresh soybean oil & 0.909 & 0.31 & 186 & 184.8 & 1.17 & 0.36 & 105.47 \\
\hline Rupchanda soybean oil & 0.9155 & 0.42 & 193 & 183.3 & 1.21 & 0.42 & 109.96 \\
\hline Deshi/Ghani mustard oil & 0.9683 & 0.21 & 171 & 158.55 & 8.78 & 0.56 & 83.1 \\
\hline Teer mustard oil & 0.9236 & 0.27 & 165 & 166.22 & 8.91 & 0.69 & 80.57 \\
\hline Suresh mustard oil & 0.919 & 0.25 & 169 & 172.75 & 8.84 & 0.62 & 73.19 \\
\hline Jui coconut oil & 0.9076 & 0.30 & 174 & 211.4 & 8.61 & 18.04 & 6.48 \\
\hline Gondhoraj coconut oil & 0.911 & 0.38 & 177 & 204.12 & 8.54 & 16.09 & 8.16 \\
\hline Olive oil & 0.906 & 0.47 & 160 & 185.8 & 12.43 & 4.2 & 78.38 \\
\hline Rice bran oil & 0.913 & 0.82 & 178 & 203.31 & 1.43 & 1.11 & 88.07 \\
\hline Palm oil & 0.9117 & 0.20 & 175 & 198.2 & 1.05 & 0.94 & 44.82 \\
\hline Castor oil & 0.943 & 0.77 & 183 & 177.28 & 6.02 & 1.89 & 84.95 \\
\hline Almond oil & 0.907 & 0.69 & 195 & 196.13 & 5.08 & 1.4 & 92.91 \\
\hline
\end{tabular}

about $95 \%$ of fatty acid in coconut oil is saturated so they have very low $\mathrm{C}=\mathrm{C}$ double bond which have low iodine number that is minimum unsaturation whereas higher the values indicate the higher unsaturation of the oils [13]. The lower the values the greater the oxidative storage stability. The oxidative and chemical changes in oils during storage are characterized by an increase in free fatty acid contents and adecrease in the total unsaturation of oils [17].

\section{CONCLUSION}

The observation results concluded that we should consider the physicochemical properties for selecting a good type edible oil. The study shows that when the peroxide value is high, the iodine value is also high but not vice versa. It also reveals that oils with low free fatty acids tend to have high boiling point and low peroxide value which are good quality attributes of ideal edible oils.

\section{COMPETING INTERESTS}

Authors have declared that no competing interests exist.

\section{REFERENCES}

1. Zahir E, Rehana S, Mehwish AH, Anjum Y. Study of physicochemical properties of edible oil and evaluation of frying oil quality by Fourier Transform-Infrared (FT-
IR) spectroscopy. Arabian J Chem; 2014. (In press).

Available:http://dx.doi.org/10.1016/j.arabjc. 2014.05.025

2. Kabagambe EK, Baylin A, Ascherio A, Campos H. The type of oil used for cooking is associated with the risk of nonfatal acute myocardial infarction in Costa Rica. J Nutri. 2005;135(11):267479.

3. Bhattacharya AB, Sajilata MG, Tiwari SR, Singhal R. Regeneration of thermally polymerized frying oils with adsorbents. Food Chem. 2008;110:562-70.

4. Ceriani R, Paiva FR, Alves CBG, Batista EAC, Meirelles AJA. Densities and viscosities of vegetable oils of nutritional value. J Chem Eng Data. 2008;53(8): 1846-53.

5. Farhoosh R, Moosai SMR, Sharif A. Investigation on frying oils quality in terms of color index, refractive index and viscosity during frying process. J Food Sci Tech. 2008;5(1):13-19.

6. Jinfeng $P$, Huixing $S$, Juan $Y$, Yong $K L$. Changes in physiochemical properties of Myofibrillar protein from silver carp (Hypophthalmich thysmollitrix) during heat treatment. J Food Biochem. 2011;35:93952.

7. SON, Standards for Edible Refined Palm Oil and Its Processed Form. 2000;2-5.

8. Birnin-Yauri, Garba. Comparative studies on some physicochemical properties of Baobab. Nigerian J Basic App Sci. 2011;19(1):64-67. 
9. The American Oil Chemists Society (AOCS) Official Method Cd 3-25; 2016.

10. Ekwu FC, Nwagu A. Effect of processing on the quality of cashew nut oils. J Sci Agric Food Tech Environ. 2004;4:10510.

11. AOCS. In: Official methods and recommended practice of the American Oil Chemist Society, $5^{\text {th }}$ Ed. AOAC Press; 1993.

12. Li H, Zhou G, Zhang H, He Y. Chemical constituents and biological activities of saponin from the seed of Camellia oleifera. Sci Res Essays. 2010;5(25): 4088-92.

13. Marinova EM, Seizova KA, Totseva IR, Panayotova SS, Marekov IN, Svetlana M. Oxidative changes in some vegetable oils during heating at frying temperature.
Bulgarian Chem. Communi. 2012;44(1): 57-63.

14. Edcey EW. Vegetable fats and oils. American Chemical Society Monograph Series, Reinhold Publication Company, New York. 1954;582-84.

15. AOAC. Official methods of analysis. Association of Official Analytical Chemists, Washington, DC; 1984.

16. Firestone D. Determination of the iodine value of oils and fats: Summary of collaborative study. J AOAC Int. 1994;77(3):674-6.

17. Perkin EG. Effect of lipid oxidation on oil and food quality in deep frying. In: Angels, AJS (Ed.), Lipid Oxidation in Food, Chapter 18, ACS Symposium Series no. 500 ACS, American Chemical Society, Washington DC. 1992;310-21.

(C) 2016 Hasan et al.; This is an Open Access article distributed under the terms of the Creative Commons Attribution License (http://creativecommons.org/licenses/by/4.0), which permits unrestricted use, distribution, and reproduction in any medium, provided the original work is properly cited.

Peer-review history:

The peer review history for this paper can be accessed here: http://sciencedomain.org/review-history/16685 